\title{
The role of cool thermal energy storage (CTES) in the integration of renewable energy sources (RES) and peak load reduction
}

\author{
Marko Ban*, Goran Krajačić, Marino Grozdek, Tonko Ćurko, Neven Duić \\ University of Zagreb, Faculty of Mechanical Engineering and Naval Architecture, Ivana Lučića 5, 10000 Zagreb, Croatia
}

\section{A R T I C L E I N F O}

\section{Article history:}

Received 1 November 2011

Received in revised form

25 June 2012

Accepted 26 June 2012

Available online 9 August 2012

\section{Keywords:}

Buildings

Cool thermal energy storage

Renewable energy sources

Modelling

\begin{abstract}
A B S T R A C T
The building sector is one of the largest energy consumers. Even though cooling needs do not contribute a large share to the overall energy demand in temperate climates, recent trends show a tendency of large growth. This growth is related to two main drivers: cheap and affordable air-conditioning units that have overrun the market and the more frequent occurrence of hot and extremely hot weather conditions. In combination with inadequate insulation and sealing in most old buildings, both drivers contributed to new cooling installations that are significantly increasing electricity demand and peak load, even at the national level. Consequently, the use of fossil fuels in power plants and electricity import has increased. The development of sustainable buildings and the use of renewable energy sources (RES) seem to be promising solutions. However, the problem of the integration of RES in the current energy system is related to their intermittent nature and uncontrollable occurrence.

Cool Thermal Energy Storage (CTES) may play an important role in the management of peak loads and solve the intermittency problem of RES, especially when cooling storage is integrated into district cooling systems. A simple mathematical model of a system with integrated RES and CTES has been developed. Hourly system analyses have been conducted for one building, a group of buildings connected to the district cooling system and a region represented by a mixture of different demands for cool thermal energy. This paper also includes the results for the overall energy efficiency, cost effectiveness and environmental impact of the systems analysed.
\end{abstract}

(c) 2012 Elsevier Ltd. All rights reserved.

\section{Introduction}

The energy use in residential, public and commercial buildings represents a major share of the overall final energy consumption and $\mathrm{CO}_{2}$ emissions of the EU, totalling approximately $40 \%$ [1]. Thus, the potential for cost-effective energy savings in the building sector is substantial and estimated to be as high as $28 \%$ of the primary energy demand by 2020 [2]. Effective management of Cool Thermal Load in buildings by Cool Thermal Energy Storage (CTES) will garner more attention, due to the new EU Directive on the energy performance of buildings [3]. The application of CTES could lead to definite energy savings, but it also has the potential for the integration of renewable energy sources (RES) and could make zero energy buildings more achievable.

Market research published in 2005 by CENERG shows that only $27 \%$ of the European tertiary sector (schools, hospitals, offices, hotels, restaurants, shops) and $5 \%$ of the residential sector are

\footnotetext{
* Corresponding author. Tel.: +385 16168 494; fax: +385 16156940

E-mail address: marko.ban@fsb.hr (M. Ban).
}

equipped with room air conditioners. It is expected that in the next decade, the EU market will reach the saturation rate of $60 \%$ for the service sector and $40 \%$ for the residential sector, showing a fourfold increase of the cooling market between 2000 and 2018. This increase corresponds to a cooling demand of $500 \mathrm{TW} \mathrm{h}_{\mathrm{c}}$ with an electricity demand of $200 \mathrm{TW}$ h for the countries of the EU [4]. Cooling appliances had a $10 \%$ share of tertiary electricity consumption in EU27 in 2004 [2]. For Croatia, Grozdek [4] estimated the total potential of the cooling demand to be $5 \mathrm{TWh}$ with an electricity demand of $1.8 \mathrm{TW}$ h while Pukšec [5] described methodology for calculation of energy consumption of a households sector which also includes needs for space cooling and related electricity consumption.

Application of CTES in buildings and energy systems has many advantages [6]. If properly designed, CTES can lower the required chiller capacity and related investment and operation costs, as presented by Andrepont [7] and Grozdek [4]. Scheduling chillers to fill the CTES during the night allows them to operate more efficiently because night temperatures are lower than those during the day, and electricity cost is also possibly lower. Deferred loads also decrease the daily peaks $[8,9]$. Beside buildings, CTES are efficiently 
applied to various industrial processes and district cooling systems. Moreover, it represents effective storage for RES integration (as seen in Lund et al. [10]), which a new subject that requires more attention from researchers.

The paper is organised into four major sections: Motivation and background, Methodology and model, Case studies and Results and, finally, the Conclusion.

\section{Motivation and background}

In this section, the main incentives for conducting research are stated with a short description of CTES technology and operation principles.

\subsection{Directive 2010/31/EU}

One of the major drivers that could revolutionise the construction of new buildings and drastically change the primary energy consumption of the building sector is the new Directive 2010/31/EU of the European Parliament and the Council on the energy performance of buildings from May 19th 2010 [3]. The important Article 9 prescribes that Member States shall ensure that all new buildings are near zero-energy by December 31st 2020 and that after December 31st 2018, new buildings, occupied and owned by public authorities, are also near zero-energy. In addition to this article, the Directive prescribes the requirements on the building envelope, ventilation heating and cooling. The minimum energy performance requirements that are not cost-effective over the estimated economic lifecycle are not required and thus do not need to be prescribed. When setting requirements, member states may differentiate between new and existing buildings and different categories of buildings.

Before starting the construction of new buildings in all member states, it will be necessary to assess the technical, environmental and economic feasibility of high-efficiency alternative systems, such as the following:

a) decentralised energy supply systems based on energy from renewable sources:

b) cogeneration; c) district or block heating or cooling, particularly where it is based entirely or partially on energy from renewable sources;

d) heat pumps.

The same directive describes 'district heating' or 'district cooling' as the distribution of thermal energy in the form of steam, hot water or chilled liquids, from a central source of production through a network to multiple buildings or sites, for the use of space or process heating or cooling.

For further development of CTES, it is important for the analysis of alternative systems to be carried out for individual buildings, groups of similar buildings, or common typologies of buildings in the same area. As far as collective heating and cooling systems are concerned, the analysis may be carried out for all buildings connected to the system in the same area.

\subsection{Intermittency, energy independency and energy storage}

Even with new buildings having minimised energy consumption, there will be certain commodities that will require a specific form (amount) of energy, making the energy neutrality of buildings achievable only through intensive integration of RES. Problems that occur in systems with high RES penetration are mostly related to the intermittent and uncontrollable nature of RES. Integration problems have been tackled by many authors, and they mostly propose solutions in the form of various types of energy storage, as shown, for instance, by Krajačić et al. in Refs. [11,12]. Most of these problems attempt to solve the integration problems from the side of the energy system, and it is interesting that, until now, CTES did not receive proper attention as storage for RES integration on the local level and also for regional or even national energy systems. Most studies related to CTES propose it as a solution for cost reduction and peak load management, emphasising the related financial and environmental benefits. In addition to these proven benefits, CTES will certainly help to reduce the variability of primary sources and also to reach a certain level of energy independency, thus increasing security for the energy supply. As it has also been highlighted, energy storage is important pillar of a post carbon society (shown by Krajačić et al. in Ref. [13]) and a crucial step for the achievement of $100 \%$ RES systems [14].

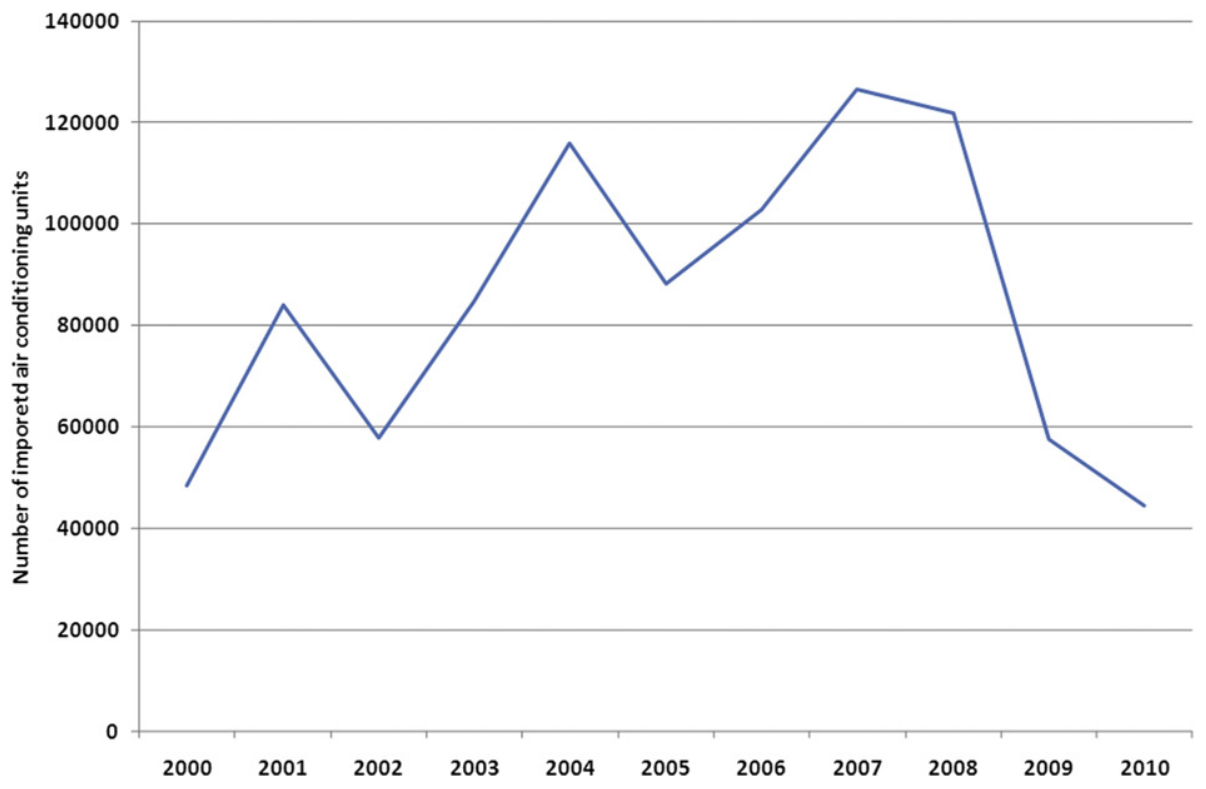

Fig. 1. Number of imported air conditioning units in Croatia (Source: Croatian Bureau of Statistics, Foreign office). 
Table 1

Increase in the average temperatures for the most populated cities in Croatia in the period 2007-2010 [17].

\begin{tabular}{llllll}
\hline City & Population & $\begin{array}{l}\mathrm{C}^{\circ} \text { above } \\
\text { average } \\
\text { temperature. } \\
\text { year 2007. }\end{array}$ & $\begin{array}{l}\mathrm{C}^{\circ} \text { above } \\
\text { average } \\
\text { temperature } \\
\text { year 2008. }\end{array}$ & $\begin{array}{l}\mathrm{C}^{\circ} \text { above } \\
\text { average } \\
\text { temperature } \\
\text { year 2009. }\end{array}$ & $\begin{array}{l}\mathrm{C}^{\circ} \text { above } \\
\text { average } \\
\text { temperature. } \\
\text { Year 2010. }\end{array}$ \\
\hline Zagreb & 779,145 & 2.4 & 1.9 & 1.9 & 1.9 \\
Split & 188,694 & 2.3 & 2.0 & 1.3 & 1.4 \\
Rijeka & 144,043 & 2.0 & 2.1 & 1.9 & 1.5 \\
Osijek & 114,616 & 2.5 & 1.4 & 1.5 & 1.5 \\
\hline
\end{tabular}

\subsection{Temperatures and power load}

In Croatia, there are approximately 2 million apartments, with more than $45 \%$ built before 1970 , and the rate of housing stock increases by $1 \%$ per year [15]. The old buildings do not have proper wall insulation because they were built before any energy policies were prescribed for the building sector. The direct consequences are high winter loads in power systems, which can be directly linked to low temperatures and the use of electricity for heating purposes. Current analyses show a similar behaviour of power systems during the summer, which is related to the installation of cheap and affordable air-conditioning units that overran the market (almost one million units in the last ten years - Fig. 1) and more frequent hot and extremely hot weather conditions. Combined with inadequate insulation and sealing in most of the old buildings, there has been a significant increase of electricity demand and peak loads, even on the national level.

In the last decade, according to the Croatian Hydro Meteorological Institute, the average summer air temperatures in the four most populated cities (housing approximately one third of the Croatian population) have increased by $2.4{ }^{\circ} \mathrm{C}$ above the average temperatures measured in the period of 1961-1991, as displayed in Table 1.

Comparing the temperatures shown in Table 1 to the mean values of the national system load presented in Fig. 2, it is clear that on average, the warmest summer was in 2007 while on the other hand, it had the lowest mean load in the power system. Information on the increased power load due to the temperature increase cannot be drawn through this comparison. The better conclusion can be drawn from Table 2 and Fig. 3, where the increase of the average temperatures in August is shown together with the load increase for different years. Even with the significant influence of economic recession, the loads in 2009 were the highest, which is a direct consequence of the highest increase of temperatures at an average of $2.875^{\circ} \mathrm{C}$ in the four major cities.

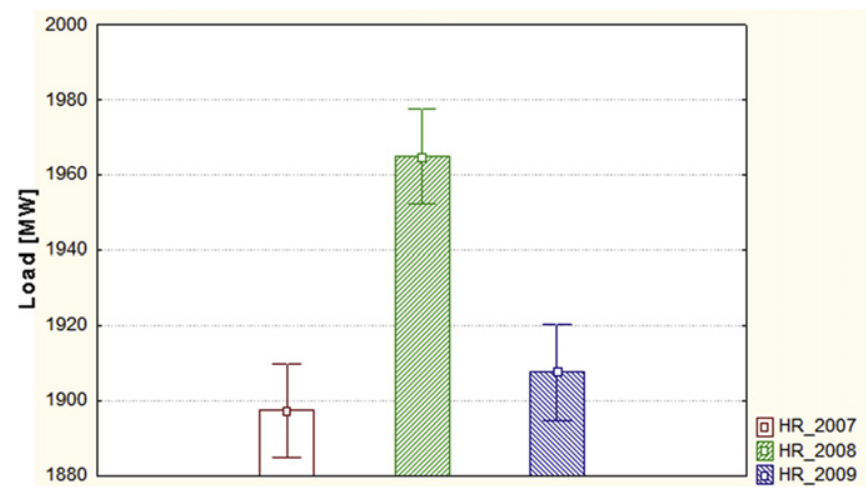

Fig. 2. Mean hourly load of the Croatian power system in MW for the period June-September and \pm 0.95 Conf. Interval [16].
Table 2

Increase in the average temperatures in August for the most populated cities in Croatia in the period 2007-2010 [17]

\begin{tabular}{llllll}
\hline City & Population & $\begin{array}{l}\mathrm{C}^{\circ} \text { above } \\
\text { average } \\
\text { temperature. } \\
\text { August 2007. }\end{array}$ & $\begin{array}{l}\mathrm{C}^{\circ} \text { above } \\
\text { average } \\
\text { temperature. }\end{array}$ & $\begin{array}{l}\mathrm{C}^{\circ} \text { above } \\
\text { average } \\
\text { temperature. }\end{array}$ & $\begin{array}{l}\mathrm{C}^{\circ} \text { above } \\
\text { average } \\
\text { emperature. }\end{array}$ \\
& & August 2009. & August 2010. \\
\hline Zagreb & 779,145 & 1.4 & 1.9 & 3 & 1.1 \\
Split & 188,694 & 1.6 & 2.5 & 2.6 & 1.5 \\
Rijeka & 144,043 & 1.3 & 2.4 & 3.3 & 0.9 \\
Osijek & 114,616 & 1.9 & 1.5 & 2.6 & 1.4 \\
\hline
\end{tabular}

Fig. 4 illustrates the link between the temperature and load increase while the statistical correlations between the two are given in Table 3. As the temperature rises, the correlations increase, which could also lead to the conclusion that in this case, the load profile better traces the temperature. To calculate the detailed influence of the temperature on the summer load profile of an entire power system and on the increase in peak power requirements, a more detailed analysis of different influence parameters is needed (cooling space and cooling saturation rates; economy related activities, e.g., tourism; average size and capacity of cooling units; etc.). However, this type of analysis is out of the scope of this article.

A summer load in the Croatian power system, displayed in Fig. 5, has two daily peak periods, the first one from 10 to $16 \mathrm{~h}$ and the second one from 20 to $24 \mathrm{~h}$. The important fact is that these summer periods have more similar peak values than those during the winter loads, when the night peak component is approximately 200 MW higher than the daily one, as shown in Fig. 6.

\subsection{CTES application, operation and technology}

As previously mentioned, CTES has been effectively applied in industrial, residential and commercial buildings and district cooling systems (as shown by Gorzdek [4], Dincer et al. [19-21]). The sizing of CTES and ancillary equipment depends more on economic parameters than on the technical requirements. Similarly, operation strategies will also be assessed more from the economic side than the technical side.

There are three basic storage-sizing and operation strategies: full storage, load-levelling partial storage and demand-limiting partial storage. For the purpose of this paper, additional operation strategies for the maximisation of RES integration by CTES have

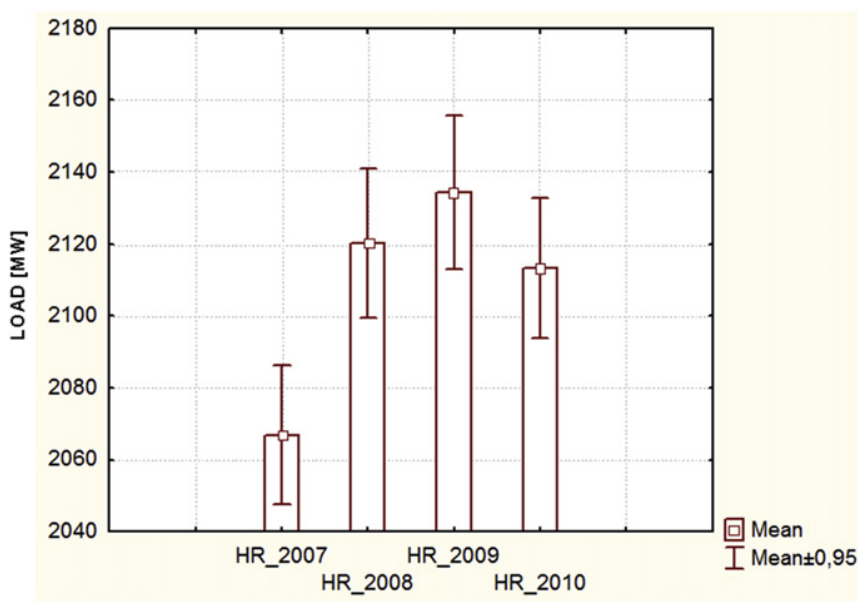

Fig. 3. Mean hourly load of the Croatian power system in MW for August (07-24 h) and \pm 0.95 Conf. Interval [16]. 


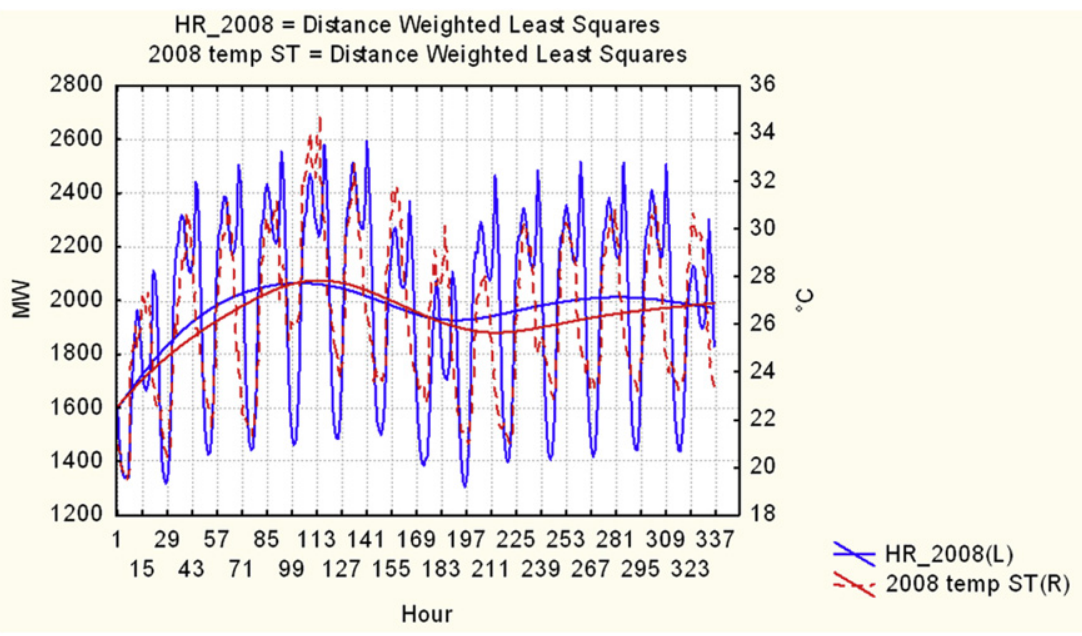

Fig. 4. Mean hourly temperatures and Croatian power load in the period 17th-30th August.

been developed and tested, as described in the next paragraph. CTES is primarily applied for the reduction of the operating costs of the system, which can be as high as $70 \%$. The payback period for using CTES is usually from 2 to 6 years, but for a more accurate prediction, several building specific pieces of information are required: the hour-by-hour power usage, the performance of the proposed cool storage system, and the tariff model of the local electrical utility, as presented by Dincer et al. in Ref. [19].

In this study, three operation strategies have been analysed. The first operation strategy of CTES that has been calculated was a night operation, where the filling of CTES was allowed only during the period of the night tariff, $22 \mathrm{~h}-08 \mathrm{~h}$. The limitation on the compressor power during daily operation was not set because it was used to partly satisfy the load after the discharge of CTES. The second strategy included RES with only PV electricity used for filling the storage and operation of compressors and thus enabling zero energy buildings. For this strategy, it was necessary to cover all available surfaces with photovoltaic modules. The third operation strategy included charging CTES only during the low tariff period and discharge during the daily peak period, which has been defined as a percentage of the maximal load in each day. In this case, CTES was discharged only when the load was above a certain limit, as defined in Table 4.

Additionally, even traditionally designed chiller plants with small efficiency improvements can multiply to create significant savings in district cooling plants. These benefits are emphasised in a larger framework, where they become more obvious and valuable. For example, district cooling is being embraced on a large scale by the United Arab Emirates to accommodate its tremendous growth, with an estimated $75 \%$ of the energy in Dubai used for

Table 3

Correlations of mean hourly temperatures measured in Split (presented by Karadža et al [18].) and Croatian hourly power load [16] for the period May-September 2008.

\begin{tabular}{lrrl}
\hline Variable & \multicolumn{1}{c}{ Means } & Std. dev. & Correlations \\
\hline May load $[\mathrm{MW}]$ & 1810.882 & 316.6377 & 0.467052 \\
May temp. $\left[{ }^{\circ} \mathrm{C}\right]$ & 20.397 & 3.8786 & \\
June load $[\mathrm{MW}]$ & 1907.903 & 348.1751 & 0.529325 \\
June temp. $\left[{ }^{\circ} \mathrm{C}\right]$ & 24.075 & 4.6856 & \\
July load $[\mathrm{MW}]$ & 2029.028 & 350.5198 & 0.547777 \\
July temp. $\left[{ }^{\circ} \mathrm{C}\right]$ & 26.676 & 3.7781 & \\
August load $[\mathrm{MW}]$ & 1967.243 & 346.2948 & 0.608089 \\
August temp. $\left[{ }^{\circ} \mathrm{C}\right]$ & 27.129 & 3.5652 & \\
September load $[\mathrm{MW}]$ & 1953.365 & 347.1538 & 0.302078 \\
September temp. $\left[{ }^{\circ} \mathrm{C}\right]$ & 20.875 & 5.7328 & \\
\hline
\end{tabular}

cooling. Rather than utilising individual cooling systems in each building, with district cooling, a reduction of $40 \%$ of the energy used is expected by the Dubai planners (see Hanson et al. [22]).

District cooling (and heating, which is out of the scope of this paper) is commonly defined as the distribution of heat transfer media from a central energy production source to meet the diverse thermal energy needs of residential, commercial, and industrial users. These needs include space cooling (or heating) systems for maintaining primarily human comfort, and manufacturing-plant process cooling (or heating) system requirements, but, despite its benefits, many of the systems installed around the world do not provide both district heating and cooling. For example, in Europe, most district systems provide only heating because of the prevailing moderate summer temperatures. North America, however, which has higher extreme summer temperatures in the southern parts (approximately $30-40{ }^{\circ} \mathrm{C}$ over extended periods), is becoming a leading region with district cooling being more widespread (Dincer et al. [23]).

The cooling for data centres will also need to be considered by district cooling systems, especially in zones with significant public and business service sectors. As shown in Ref. [2], it was envisaged that without proper action, the electricity demand of data centres in 2010 will reach nearly $70 \mathrm{TW}$ h. It was also estimated that approximately half of the electricity consumption of a data centre is due to server infrastructure (for cooling and lighting [2]).

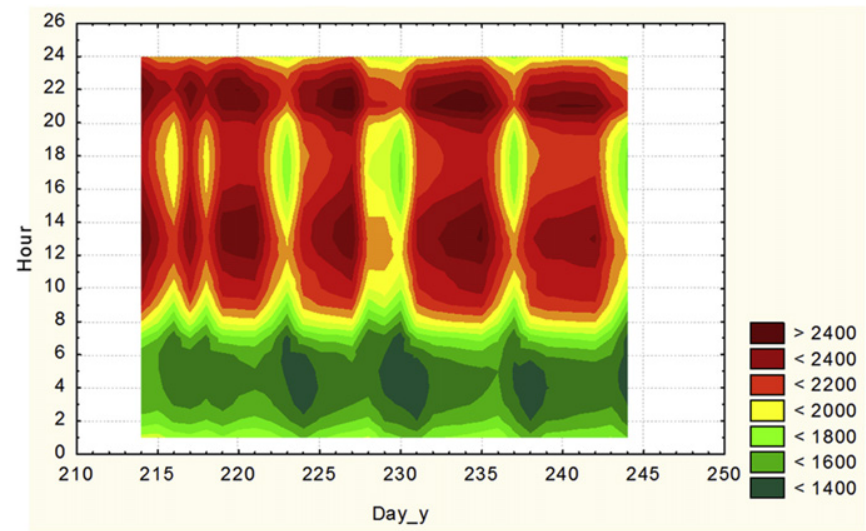

Fig. 5. Plot of the hourly mean load in August 2008 for a 24 h period [16] 


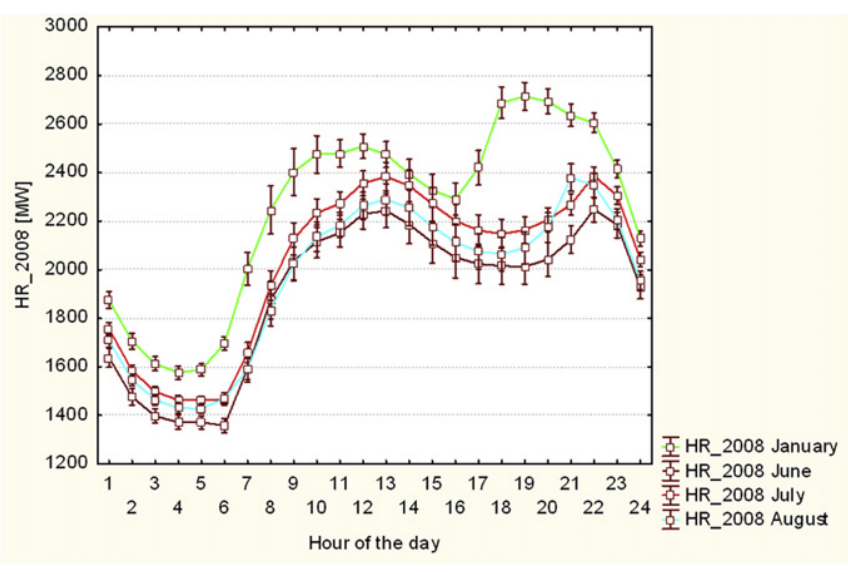

Fig. 6. Hourly mean load in the Croatian power system for days, hours, and the months January, June, July and August [16].

\subsection{Technology}

In general, CTES systems can be divided into two main types, ones using sensible heat (water) and others using latent heat (water/ice and eutectic salt hydrates). The selection of the storage type will depend on the application and desired temperatures. A review of CTES and its application for air conditioning was presented a decade ago by Hasnian in Ref. [24]. A more recent review was given by [4] with a tabular presentation of the most important characteristics of CTES.

The first of the main types of CTES systems, as mentioned previously, is sensible CTES, which stores the energy by changing the temperature of a storage medium, such as water. There is no change in phase of the storage material in the storage process dependant on the temperature range encountered. Two important parameters for TES are the quantity $\rho c_{\mathrm{p}}$, which determines the ability to store sensible heat for a given material, and the rate at which heat can be released and extracted (Dincer et al. [19]).

The second type of TES, which is receiving a great deal of interest, is the one using latent heat. Latent thermal energy storage is most obviously perceived in the conversion of water into ice. The principle is used in cooling systems incorporating ice storage. Such systems utilise the fact that ice has the ability to store a great amount of energy as latent heat, which finally becomes evident in a sizeable advantage over chilled water units of equivalent capacity because the sensible heat change (related to its specific heat) for a given medium is (usually) much smaller that the latent heat change. For example, the melting and freezing of water involves a latent heat change on the order of $0.3 \mathrm{MJ} / \mathrm{kg}$. In addition, the main advantage of latent TES systems over sensible ones besides higher capacities per unit mass is the small temperature range of operation. Because there is no gradual decline in temperature, the heat interaction occurs at a constant temperature as heat is removed from the storage material.

Table 4

A peak threshold for different months used in RES + night operation strategy.

\begin{tabular}{ll}
\hline Month & Peak threshold \\
\hline $1-5$ & 0.50 \\
6 & 0.75 \\
7 & 0.85 \\
8 & 0.85 \\
$9-12$ & 0.60 \\
\hline
\end{tabular}

When the storage material melts or vaporises, it absorbs heat, and when the opposite process, crystallisation or condensation, occurs, this heat is released. This change is used to store heat in phase change materials (PCMs), most commonly water, salt hydrates, and certain polymers. The higher energy densities of latent CTES versus sensible CTES are also the main cause of the lower storage losses in latent CTES. Charging the latent TES system with, for example, a eutectic phase change material with a phase change temperature of $8.3^{\circ} \mathrm{C}$ requires conventional chilled-water temperatures $\left(5.5{ }^{\circ} \mathrm{C}\right)$, which are also encountered in chilledwater storage systems and allows new or existing centrifugal, screw, or reciprocating chillers to be used to charge this type of TES system, making eutectics particularly appropriate for retrofit applications. The charging temperature of $5.5{ }^{\circ} \mathrm{C}$ additionally enables the chiller to operate at high suction temperatures and high compressor coefficients of performance (COP). The latent heat of fusion of phase changing materials also allows a TES to be moderate in size at approximately $0.155 \mathrm{~m}^{3}$ per ton for the entire TES system. Finally, the storage capacity is based on the amount of PCM frozen and not the temperature difference across the cooling coils, as presented by Dincer et al. in Ref. [23].

For the purpose of this research, a glycol ice storage system was used. Such CTES systems operate by freezing water with circulating ethylene or propylene glycol through storage tanks.

These systems can be divided into two major categories: modular and encapsulated ice storage. One of the advantages of the glycol ice storage systems is the low installation cost, which is governed by the fact that the chiller providing space cooling can also be used to make the ice. The only notable additional costs are the storage tanks, but sometimes introducing glycol ice storage can reduce chiller costs. Additional benefits include the ability to use a standard packaged chiller, reduce pump work and require few ancillary devices and the overall application flexibility. Conversely, the greatest disadvantage of these systems is the need for a heattransfer system to use glycol rather than water.

Overall, glycol ice-storage systems enjoy a great deal of market popularity because of their simplicity and low installed cost.

TES can aid in the efficient use and provision of thermal energy whenever there is a mismatch between energy generation and use. Various subsets of TES processes have been investigated and developed for heating and cooling in buildings, industrial applications, and utility and space power systems. The period of storage is an important factor. Diurnal storage systems have certain advantages: the capital investment and energy losses are usually low, and units are smaller and can easily be manufactured offsite. The sizing of a daily storage for each application is not nearly as critical as that for larger annual storage. Annual storage, however, may become economical only in multi-dwelling or industrial park designs and often requires expensive energy distribution systems and novel institutional arrangements related to ownership and financing. In solar TES applications, the optimum energy storage duration is usually the one that offers the final delivered energy at minimum cost when integrated with the collector field and backup into a final application (Dincer et al. [23]).

CTES provides a high degree of flexibility because it can be integrated with a variety of energy technologies, for example, solar collectors, biofuel combustors, heat pumps, and off-peak electricity generators.

\section{Methodology and model}

For the purpose of calculating the RES integration and peak load reduction through the application of CTES, a simplified mathematical model has been developed and tested for one building, a group of buildings connected to district cooling system, and 


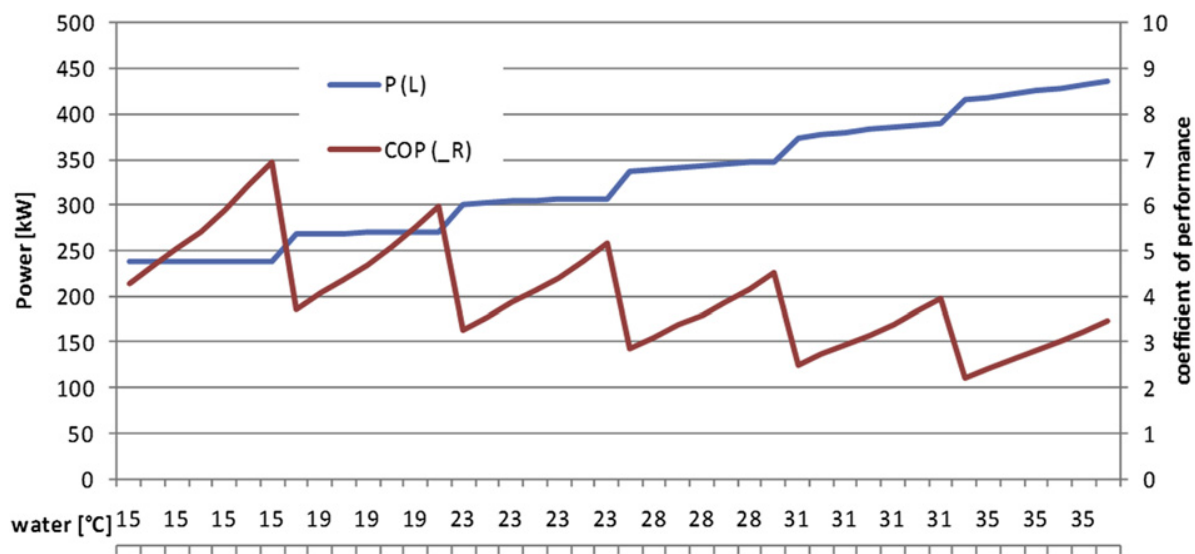

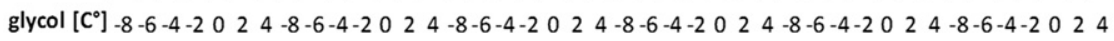

Fig. 7. York screw compressor power and COP for different inlet water and outlet glycol temperatures.

a region represented by a mixture of different demands for cool thermal energy. The solar and wind modules from the $\mathrm{H}_{2}$ RES programme have been used for the calculation of the production by PV modules and wind turbines. $\mathrm{H}_{2}$ RES is explained by Krajačić et al. [25] and Lund et al. [26]. Finally, the evaluation of different solutions has been conducted for the overall energy efficiency, cost effectiveness and environmental impact of the systems analysed.

The CTES system used in this paper is modelled according to Ref. [20] (CRYOGEL Ice Ball Thermal Storage), including chillers, tanks with encapsulated water/ice and a cooling load. The chillers are represented by the maximum and minimum electric power load per compressor, the number of units of the same power and their COPs. Tanks are represented by their count, the maximum storage capacity for the same group of tanks, and the maximum and minimum input and output loads per hour. As shown by Bédécarrats et al. in Refs. [27] and [28], one can make an approximation where the stored energy is linearly dependant during an hour of the charge/discharge process above $10 \%$ and up to $90 \%$ of the total installed capacity with a constant coolant temperature and flow rate. The thermal load is calculated for each case study and described in more detail in the following chapter.

Three operation strategies have been applied in the case studies described in the previous section. The first strategy is regarded as the referent strategy, where the storage was filled only during the night or low tariff period, in which chillers were used partly for covering the load and filling the storage. Second, there was the RES strategy, where the storage was filled only by available RES electricity, and finally, there was the RES + night strategy as a combination of the first two.

Grozdek concluded in Ref. [4] that it is impossible to find a rather simple, fast, yet sufficiently accurate method to describe the performance of CTES systems over time, which is also supported by the mathematical model developed by Bédécarrats et al. [28], mostly due to the high process complexity and nonuniformity throughout the CTES system (the situation can differ drastically between pipe segments, pipes and modules in the same silo). A complex computer model is thus needed (also shown by modelling examples by Wei et al. in Ref. [29] or Assis et al. in Ref. [30]). The simulation results clearly show that to propose an adequate system design, no simple engineering methods or rule-of-thumb principles could be utilised. As indicated, the results of an initial sizing procedure are far from the "real" behaviour of an ice bank system.

The COP of the chillier (compressor) in the secondary cooling loop is dependent on the desired outlet temperature of the glycol and inlet temperature of the cooling water. The COP increases as the inlet water temperature decreases and outlet glycol temperature increases, as presented in Fig. 7. Thus, there is another reason why detailed models of CTES systems are required because the COP

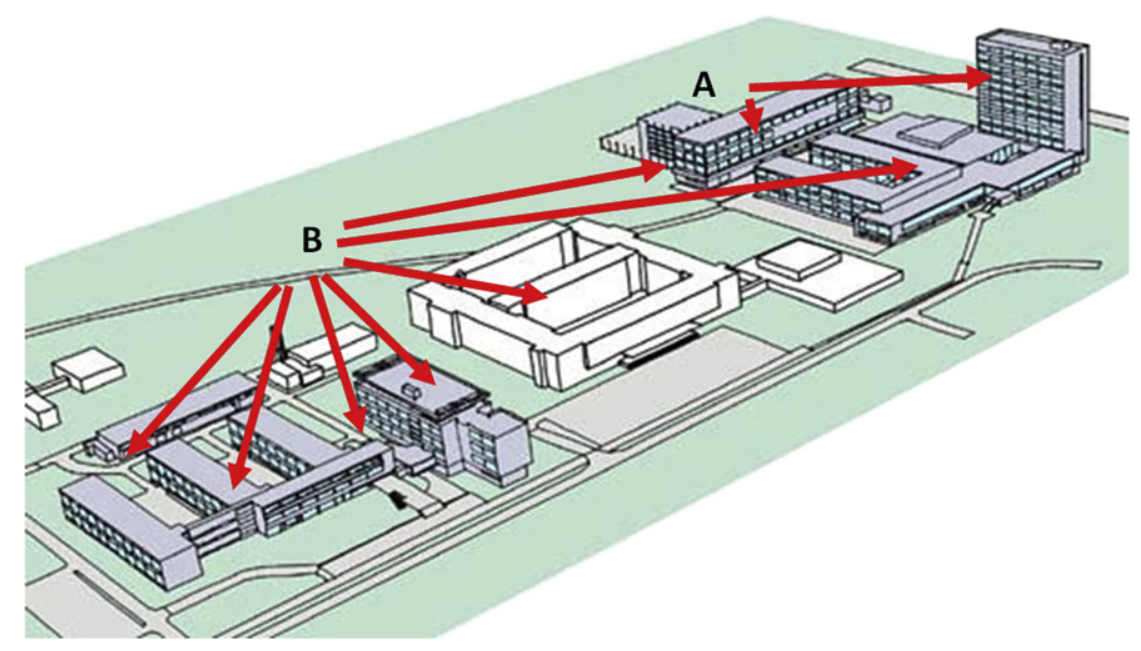

Fig. 8. Buildings used for simulation in case studies A and B. 


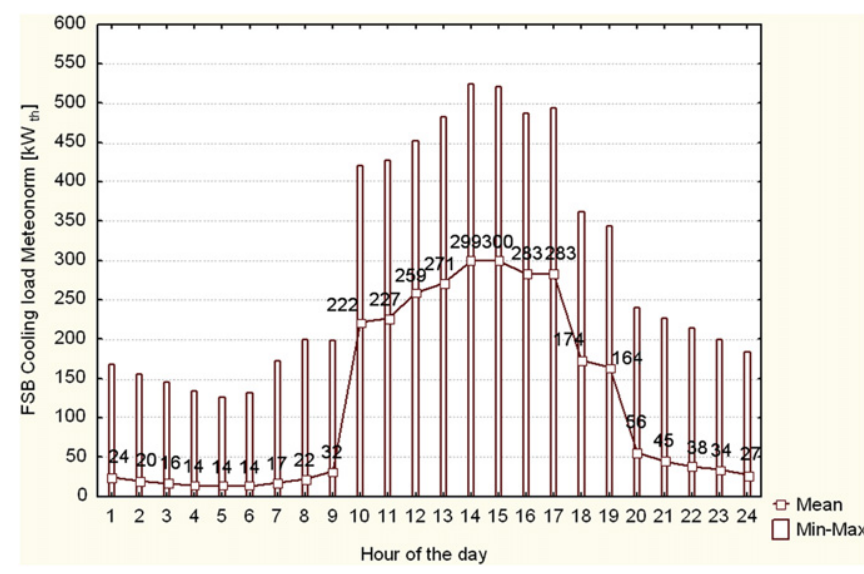

Fig. 9. Mean, Min and Max thermal load of the FSB building in case study A for the period June-September.

increase gained during the night operation of the chiller could be lost due to a decrease in the required lower temperatures of glycol. Without a detailed analysis of the primary cooling loop, the COP has been set to 3 in all calculations except one calculation (Case B, explained in the next section), where it has been set to 4, assuming that it will still lead to important conclusions on RES integration and peak load reduction.

The final part includes the results for economic and environmental analysis where the calculated benefits are presented. The economic analysis has been conducted by formulae for the calculation of investment costs taken from various literature sources, the operation and maintenance costs during the equipment life time of 20 years, by the application of discount rates of $10 \%$ and using the two tariff models for electricity costs that are currently valid in Croatia and used by the Croatian utility company for the electricity distribution HEP-ODS.

\section{Case studies and results}

As previously mentioned, three case studies for CTES applications have been analysed, including one building (Case A), a group of buildings (Case $B$ ) and a regional energy system (Case $C$ ). The buildings considered are presented in Fig. 8, and they form the main buildings and offices (campus) of the two faculties at the University of Zagreb (Faculty of Mechanical Engineering and Naval Architecture - FSB, and Faculty of Humanities and Social Sciences FFZ).

The hourly thermal load profile for the building in Case A has been calculated with the use of meteorological data provided by the METEONORM programme [31]. Data include the hourly solar radiation, air temperatures and wind speeds for the city of Zagreb. The thermal load of the FSB building in Case Study A is given in Fig. 9, including the mean, minimum and maximum values for the period of June to September. The thermal load has a typical pattern with peak loads in the period from $10 \mathrm{~h}$ to $18 \mathrm{~h}$ and the maximum load from $14 \mathrm{~h}$ to $15 \mathrm{~h}$. In this period, the mean load is 10 times higher than the off peak load during the night while maximum values are $2-3$ times higher.

The thermal load for Case B also includes a separate building of FSB and the campus of FFZ. With nearly the same daily routine in the separate block of FSB as in the main one but with fewer staff and students, it was simply derived as a $60 \%$ addition to the thermal load of the main building.

Because there was no available data for FFZ, it was also derived from the FSB main building data with a few considerations. Because this faculty has a higher number of staff and students but no laboratories, it was assumed that the total daily thermal load for both facilities is at the same level. The daily routine of the institutions is, however, different because FFZ has lectures in the evening hours. Thus, the thermal load for FFZ was extended from 17 to $21 \mathrm{~h}$, with lower peaks being observed in the afternoon to maintain the same daily load as the FSB.

The peak thermal load in the Case A was set to $524 \mathrm{~kW}_{\text {th }}$, and the total amount of cooling energy that needs to be supplied (removed heat energy) was $434,935 \mathrm{~kW} \mathrm{~h}_{\mathrm{th}}$. The required total electric power for the compressors of the chillers for COP $=3$ is shown in Fig. 10. The maximum power encountered was $175 \mathrm{~kW}$ with electricity consumption of $144,978 \mathrm{~kW}$ h. Fig. 10 also shows that the cooling and related compressor loads depend significantly on the seasons and months, which could result in solutions with oversized equipment and low load factors.

In Case A, the total horizontal surface available for the installation of fixed PV modules under an optimal inclination angle was estimated to be $5500 \mathrm{~m}^{2}$, of which it is assumed that only $40 \%$ will

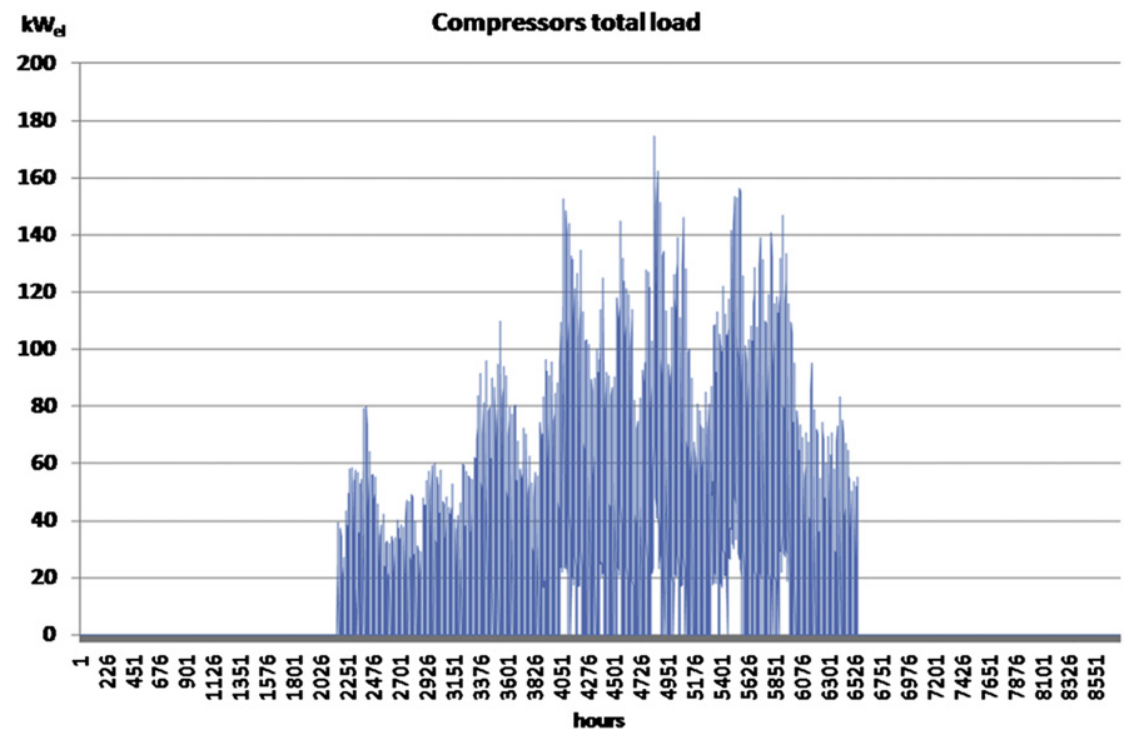

Fig. 10. Power load of compressor in case A before the application of the CTES system. 


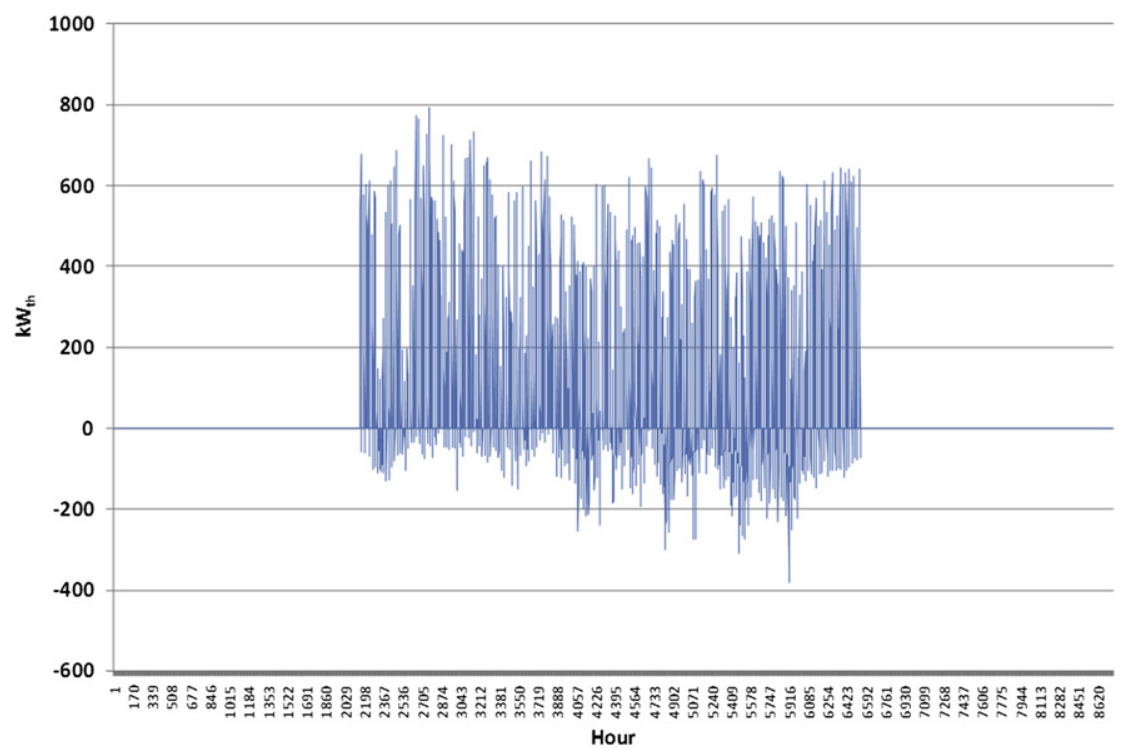

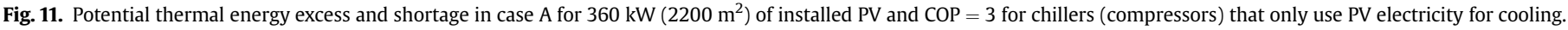

be covered by PV (the module surface), due to shadowing, different obstacles and building code requirements. The similar total surface in Case B was $11,000 \mathrm{~m}^{2}$, or $4400 \mathrm{~m}^{2}$ of the surface of the PV module. Data for the hourly solar radiation on the horizontal surface for Zagreb have been obtained from the METENORM programme and have been adjusted by $\mathrm{H}_{2}$ RES and PV-GIS [32] programmes for radiation at the optimal angle. The total yearly radiation on the horizontal surface was $1210 \mathrm{~kW} \mathrm{~h} / \mathrm{m}^{2}$ or, at an

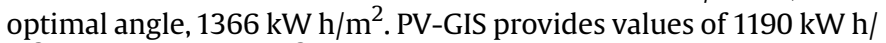
$\mathrm{m}^{2}$ and $1350 \mathrm{~kW} \mathrm{~h} / \mathrm{m}^{2}$, respectively. The solar atlas of Republic of Croatia by Matić [33] gives a value of $1220 \mathrm{~kW} \mathrm{~h} / \mathrm{m}^{2}$ for Zagreb. PV-GIS also provides the optimised slope and tracking around the vertical axis equal to $1670 \mathrm{~kW} \mathrm{~h} / \mathrm{m}^{2}$, tracking around the horizontal axis gives $1660 \mathrm{~kW} \mathrm{~h} / \mathrm{m}^{2}$, and two-axis tracking provides a value of $1700 \mathrm{~kW} \mathrm{~h} / \mathrm{m}^{2}$. Fig. 11 shows theoretically available cooling thermal energy excess and shortage if all electricity is used by the compressors. The potential is approximately 3 times higher than the cooling load requirements with approximately $20 \%$ unsatisfied cooling, which is mostly due to the night loads.

The results of calculations for Case A show that there were no major savings achieved by the installation of CTES because the

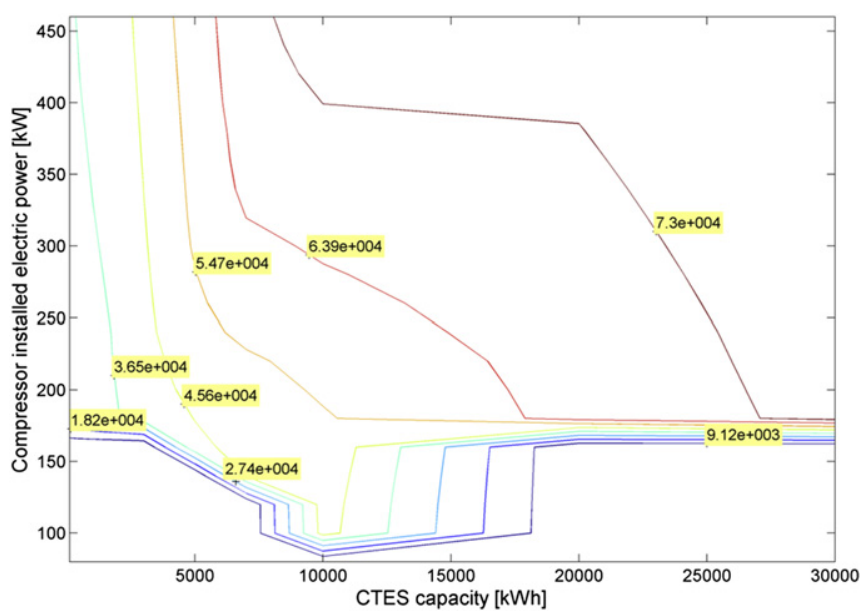

Fig. 12. Calculated total yearly costs for case A, where operation strategy = night. installation costs of CTES overreached the benefits achieved by shifting the operation of compressors in the night mode. The total yearly costs of installation without storage were 27,301 EUR, which includes 20,122 EUR for electricity cost according to the "red tariff model" applicable to FSB and 6690 EUR for discounted yearly installation and operation and maintenance costs for $2 \times 90 \mathrm{~kW}$ compressors. The smallest CTES installation decreased the costs of electricity by $40 \mathrm{EUR}$, and the difference between the high tariff and low tariff period is at $1.5 \mathrm{cEUR} / \mathrm{kW} \mathrm{h}$, which means that the operation strategy of CTES was not optimised theoretically. If it is possible to utilise all of the CTES capacity to shift the loads to the low tariff period during the 182 cooling days, then the hypothetical maximal achieved savings are 273 EUR. Figs. $12-15$ present the increase of the total yearly costs and total electricity costs for various sizes of compressors and CTES.

Assuming that a $2 \%$ unsatisfied cooling load on a yearly basis is acceptable, there are many options for district cooling systems to satisfy the majority of cooling needs with PV panels installed on the

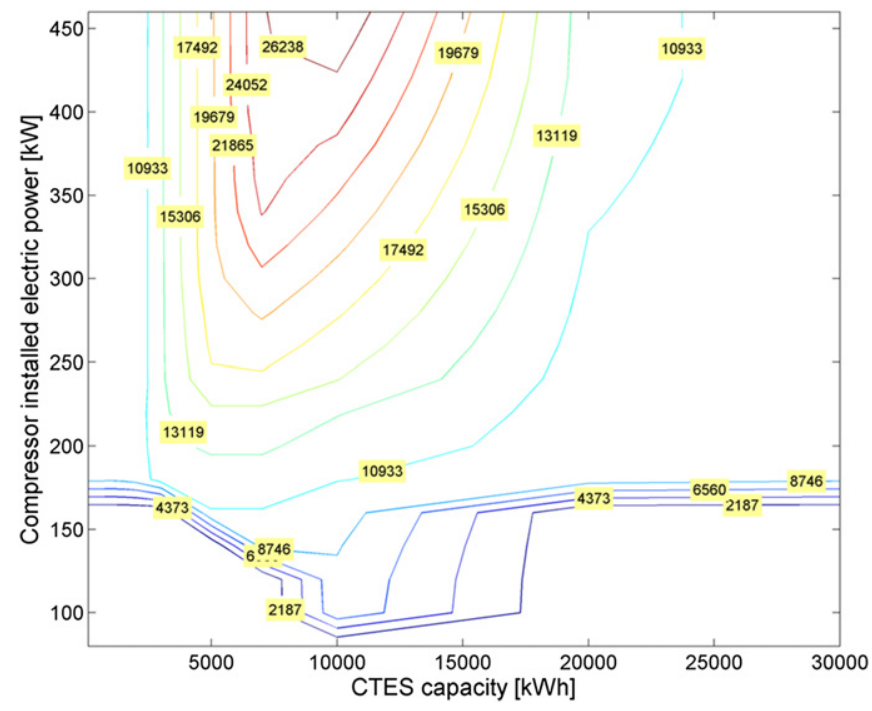

Fig. 13. Total electricity cost in case A, where operation strategy = night. 


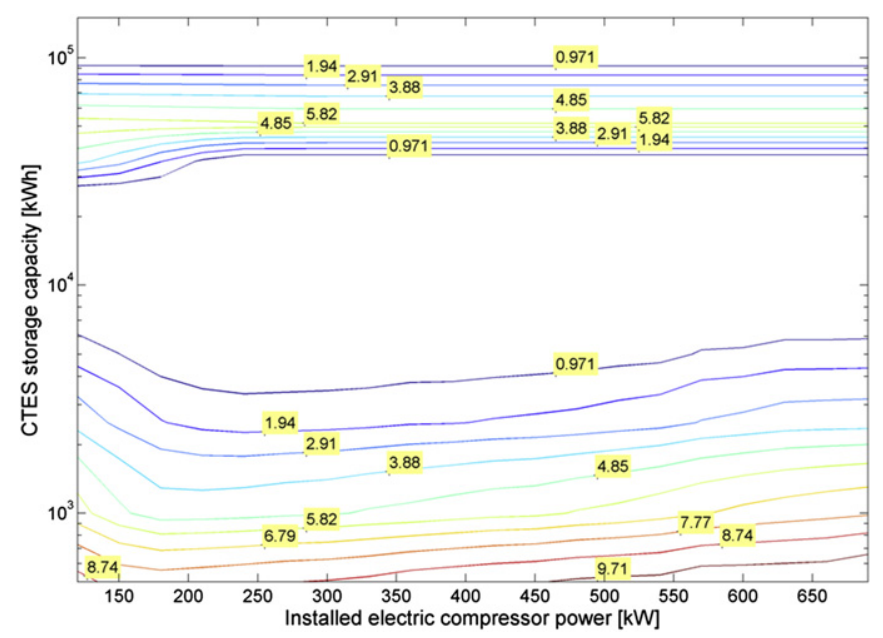

Fig. 14. Percentage of unsatisfied load for Case B and the RES operation strategy.

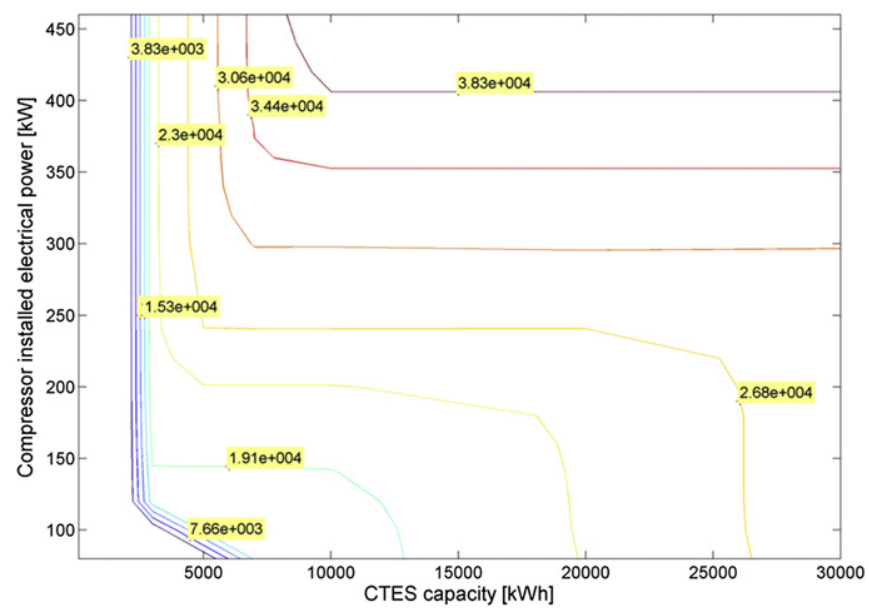

Fig. 15. Total yearly electricity cost in case A and the operation strategy RES + night.

roofs of the buildings analysed. Unfortunately, this option is not economically attractive because at this moment, the prices of CTES and PV are too high.

The financially most attractive option has been calculated by applying the RES + night operation strategy to Case A. Using this strategy, CTES was charged during the night, while all PV electricity was sold to the grid with assumed feed in tariff for support of the production of electricity by building integrated PV at $32.22 \mathrm{cEUR/}$

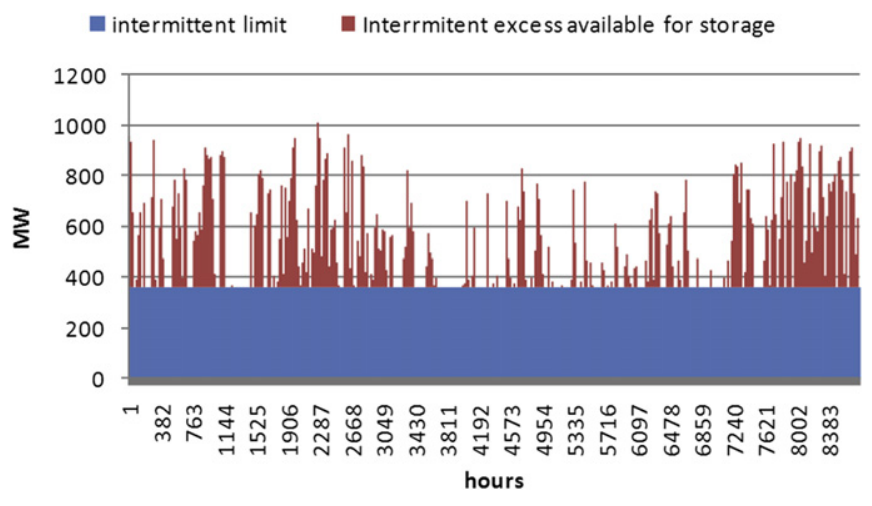

Fig. 17. Intermittent limit and excess available for storage.

$\mathrm{kW}$ h. In this case, for the optimal solution, the total discounted yearly installation and $O$ and M costs were 142,284 EUR, while the income from PV production was 144,618 EUR, with an additional 17,431 EUR of electricity costs that should be charged. Thus, even this solution is not economically feasible under the present circumstances. Moreover, the feed in tariff is given only for 12 years; therefore, even with the calculated increase in electricity costs in the period after the tariff is given, the present value of the project is $-181,705$ EUR for a 20 -year period.

The regional cooling load used in the calculations of Case $C$ has been extracted from the load of the Croatian power system. It was assumed that the regional power load is one half of the Croatian system load and that the electric power related to space cooling (Figs. 16 and 17) is equal to a certain percentage of the load that depends on the outdoor temperature. The installed power of wind turbines in the region was $1000 \mathrm{MW}$, and the power of solar PV was $54 \mathrm{MW}$. The potential for storage from intermittent sources has been calculated according to the current limit of intermittent RES penetration set by the Croatian utility to $360 \mathrm{MW}$.

The assumed cooling thermal load was $682 \mathrm{GW} \mathrm{h}$, and the thermal power $577 \mathrm{MW}$. By incorporating $7500 \mathrm{MW}$ h of CTES, the rejected excess has been reduced by $78 \%$ (compared to values without the storage). Taking into account a specific $\mathrm{CO}_{2}$ emission factor $0.33 \mathrm{~kg} / \mathrm{kW}$ h per total electricity production in Croatia in the period from 2005 to 2010 [34], reduced emissions due to covering of regional cooling thermal load by intermittent RES are $75110 \mathrm{t}$ $\mathrm{CO}_{2}$. Calculated reduction is valid with the assumption that each $\mathrm{kW} h$ of electricity from RES replaced one $\mathrm{kW} h$ generated in Croatia. From the global point of view reduction of $\mathrm{CO}_{2}$ emissions may be even higher if import of electricity from the regions with dominant coal power plants were replaced. Similar to reduction of $\mathrm{CO}_{2}$ emissions $\mathrm{SO}_{2}, \mathrm{NO}_{x}$ and particle emission could be estimated.

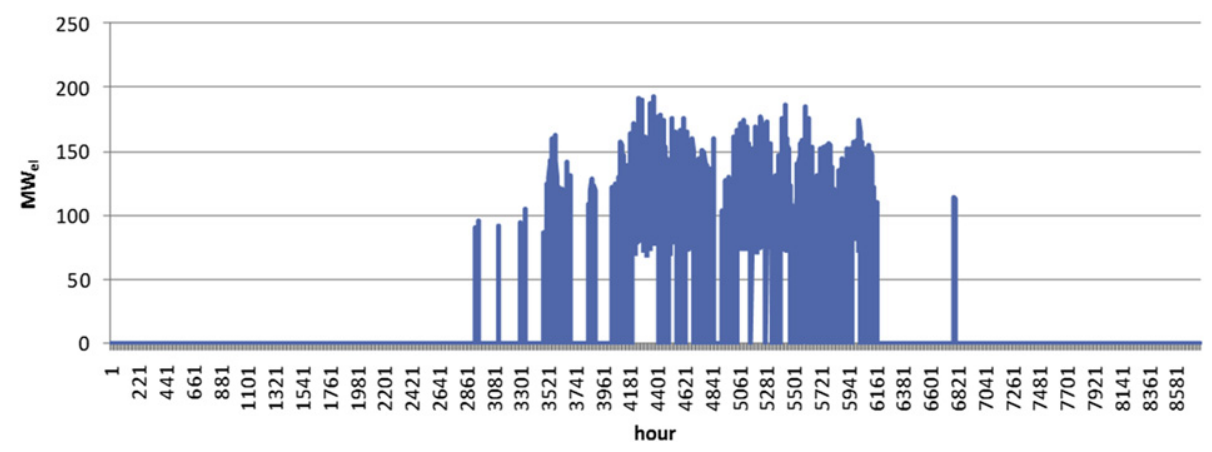

Fig. 16. Regional power system load related to space cooling in case C. 


\section{Conclusion}

The work in this paper investigated the potential of using CTES combined with RES for cooling needs in the building sector. As reference cases, the campuses of the Faculty of Mechanical Engineering and Naval Architecture and the neighbouring Faculty of Humanities and Social Studies have been used to validate the principles of CTES modelling for a single building and also for a district cooling system.

A simplified mathematical model has been developed for the CTES system and combined with existing $\mathrm{H}_{2} \mathrm{RES}$ software, which is used to analyse hourly system for one or more buildings. The results for the overall energy efficiency, cost effectiveness and environmental impact have been presented.

It was shown that the cooling and related compressor loads depend significantly on the seasons and months, which could result in oversized equipment with low load factors.

PV tracking options have not been included in the analysis because they will require an additional optimisation process that will take into account additional surfaces and costs related to those systems. In addition, as shown by the use of the daily peak limit for CTES charge and discharge, the system operation could be additionally optimised, but it require more detailed models.

Several test strategies have been considered, and the one providing the best results was with CTES charged during the night while all PV electricity is sold to the grid according to the Croatian feed in tariffs for the support of the production of RES electricity.

It will definitely be worth calculating a case with batteries, which will be more expensive, but if larger COPs could be achieved, for example, with underground water to cool the chillers, and electric vehicles pushing the battery industry to cut the cost of their production, perhaps batteries are also attractive for storage and could be coupled with chillers to serve the cooling load efficiently by storing the PV excess production, overall representing a very interesting topic for future work.

\section{References}

[1] EC - Directorate General for Energy. Expert workshop on the comparative framework methodology for cost optimal minimum energy performance requirements. Meeting document. Brussels: European Comission; 2011.

[2] Fraunhofer Institut. Study on energy savings potentials in EU member states, candidate countries and EEA countries. Project Final report. Karlsruhe/Grenoble/Rome/Vienna/Wuppertal: Fraunhofer-Institute for Systems and Innovation Research; 2009. TREN/D1/239-2006/S07.66640.

[3] European Parliament. Directive on the energy performance of buildings. Directive. Brussels: Official Journal of the European Union; 2010. European Parliament and the Council. 2010/31/EU.

[4] Grozdek M. Load shifting and storage of cooling energy through ice bank or ice Slurry systems. PhD Thesis. Stockholm: KTH; 2009 Royal Institute of technology. ISBN 978-91-7415-434-4.

[5] Pukšec T, Mathiesen BV, Duić N. Potentials for energy savings and long term energy demand of Croatian households sector. Applied Energy, in press.

[6] ASHRAE. Thermal storage. In: ASHRAE handbook. Atlanta, USA: American Society of Heating, Refrigerating, and Air-Conditioning Engineering, Inc: 2007.

[7] Andrepont JS. Development in thermal energy storage: large applications, low temps, high efficiency and capital savings. In: Proceedings of Association of energy Engineers (AEE) world energy Engineering Congress; 2005
[8] Tariff models and prices. [Internet]. [Cited 2011]. Available from: http://www. hep.hr/ods/en/customers/Tariff.aspx.

[9] Croatian Power System, daily power load curve. [Internet]. [Cited 2008]. Available from: http://www.hep.hr/ops/hees/dijagram.aspx.

[10] Lund $\mathrm{H}$, Kempton W. Integration of renewable energy into the transport and electricity sectors through V2G. Energy Policy 2008;36(9):3578-87.

[11] Krajačić G, Duić N, Tsikalakis A, Zoulias M, Caralis G, Panteri E, et al. Feed-in tariffs for promotion of energy storage technologies. Energy Policy 2011; 39(3):1410-25.

[12] Krajačić G, Martins R, Busuttil A, Duić N, Carvalho MG. Hydrogen as an energy vector in the islands' energy supply. International Journal of Hydrogen Energy 2008 February;33(4):1091-103.

[13] Krajačić G, Duić N, Zmijarević Z, Vad Mathiesen B, Anić Vučinić A, Carvalho MDG. Planning for a $100 \%$ independent energy system based on smart energy storage for integration of renewables and $\mathrm{CO}_{2}$ emissions reduction. Applied Thermal Engineering 2011;31:2073-83.

[14] Krajačić G, Duić N, Carvalho MG. How to achieve a 100\% RES electricity supply for Portugal? Applied Energy 2011;88:508-17.

[15] Intelligent Energy Europe programme. Implementing the energy performance of buildings directive (EPBD). Brussels: European Union Publications Office; 2011.

[16] ENTSO-E. Resources. [Internet]. [Cited 2010 April 10]. Available from: https:// www.entsoe.eu/.

[17] Croatian Hydro Meteorological Institute. Državni hidrometeorološki zavod Klimatologija. [Internet]. [Cited 2011 March]. Available from: http://klima.hr/ ocjene_arhiva.php.

[18] Karadža N, Horváth L, Matić Z. Progress of wind resource assessment program in Croatia. In: European Wind Energy Conference \& Exhibition; 31 March-3 April 2008; Brussels Expo, Belgium. p. http://www.ewec2008proceedings. info/index2.php?page $=$ searchresult\&searchin $=2$.

[19] Dincer I, Rosen MA. Thermal energy storage: systems and applications. 2nd ed. Chennai: John Wiley \& Sons Ltd; 2011.

[20] CRYOGEL. CRYOGEL Thermal energy storage. [Internet]. [Cited 2011 May]. Available from: http://www.cryogel.com/.

[21] Cristopia Energy Systems. Cristopia energy systems. [Internet]. [Cited May 2011]. Available from: http://www.cristopia.com/.

[22] Hanson SS. District cooling systems. In: Capehart BL, editor. Encyclopedia of energy engineering and technology, Vols. I-III. Boca Raton: Taylor \& Francis Group, LLC; 2007.

[23] Dincer I, Hepbasli A. District energy systems. In: Encyclopedia of energy engineering and technology, Vols. I-III. Boca Raton: Taylor \& Francis Group, LLC; 2007.

[24] Hasnain SM. Review on sustainable thermal energy storage technologies. Part II: cool thermal storage. Energy Conversation and Management 1998;39(11): 1139-53.

[25] Krajačić G, Duić N, Carvalho MG. H2RES, Energy planning tool for island energy systems - the case of the Island of Mljet. International Journal of Hydrogen Energy 2009 August;34(16):7015-26.

[26] Lund H, Duic N, Krajacic G, Carvalho MG. Two energy system analysis models: a comparison of methodologies and results. Energy 2007;32(6):948-54.

[27] Bédécarrats JP, Castaing-Lasvignottes J, Strub F, Dumas JP. Study of a phase change energy storage using spherical capsules. Part I: experimental results. Energy Conversion and Management 2009;50:2527-36.

[28] Bédécarrats JP, Castaing-Lasvignottes J, Strub F, Dumas JP. Study of a phase change energy storage using spherical capsules. Part II: numerical modelling. Energy Conversion and Management 2009;50:2537-46.

[29] Wei J, Kawaguchi Y, Hirano S, Takeuchi H. Study on a PCM heat storage system for rapid heat supply. Applied Thermal Engineering 2005;25(17-18): 2903-20.

[30] Assis E, Katsman L, Ziskind G, Letan R. Numerical and experimental study of melting in a spherical shell. International Journal of Heat and Mass Transfer 2006:50(9-10):1790-804.

[31] METEOTEST. METEONORM. [Internet]. Available from: http://www. meteonorm.com/pages/en/meteonorm.php.

[32] JRC. GIS Assessment of Solar Energy Resource in Europe. [Internet]. [Cited 2010 May 10]. Available from: http://re.jrc.cec.eu.int/pvgis/pv/index.htmd.

[33] Matić Z. Solar radiation atlas for the area of the Republic of Croatia. In: Proceedings of the first International Forum of the renewable energy sources; 2004.

[34] Energy in Croatia - annual energy report. Zagreb: Ministry of Economy, Labour and Entrepreneurship, Republic of Croatia; 2011. 